\title{
Biostimulation as a process aiding tebuconazole degradation in soil
}

\author{
Małgorzata Baćmaga ${ }^{1} \cdot$ Jadwiga Wyszkowska ${ }^{1}$ (D) Jan Kucharski ${ }^{1}$
}

Received: 25 January 2019 / Accepted: 5 April 2019 /Published online: 24 April 2019

(C) The Author(s) 2019

\begin{abstract}
Purpose The purpose of this study was to compare effects of two biostimulating substances (compost and bird droppings) on the proliferation of microorganisms, enzymatic activity, and resistance of spring barley in soil exposed to tebuconazole fungicide. Both biostimulating substances were also assessed for their efficacy in tebuconazole degradation in soil.

Materials and methods A pot vegetation experiment was performed with soil belonging to the Eutric Cambisols to test the effect of tebuconazole on the biological activity of soil. Its adverse effect on the biological properties of soil was minimized through the use of biostimulating substances (compost and bird droppings), the effect of which was expressed with the $\mathrm{IF}_{\mathrm{C} / \mathrm{BD}}$ index. The $R C h$ index was used to determine the effect of tebuconazole on the proliferation of soil microorganisms and enzymes, the $\mathrm{BA}_{21}$ index was used to express soil fertility based on the activity of soil enzymes, whereas the RS index - to express the resistance of spring barley to the administered doses of tebuconazole. Finally, analyses were conducted to determine the efficacy of soil amendment with biostimulating substances in tebuconazole degradation.

Results and discussion Study results demonstrate that tebuconazole caused significant changes in the proliferation of the tested groups of microorganisms, in the activity of soil enzymes, and in spring barley yield. It was especially noticeable in pots in which the soil was exposed to its highest dose, i.e., $2.499 \mathrm{mg} \mathrm{kg}^{-1}$. Soil supplementation with bird droppings had a positive effect on the development of soil microorganisms and on the enzymatic activity in the soil. In turn, compost addition to soil exerted various effects on the biological properties of soil. Both biostimulating substances failed to improve spring barley yield. Tebuconazole degradation was more intense in the soil fertilized with bird droppings than with compost.

Conclusions Results of this study suggest that tebuconazole can affect the stability and health status of soil ecosystems by modifying their biological properties. The high sensitivity of soil microorganisms and enzymes to stress conditions makes them reliable environmental bioindicators. The strive for eliminating the adverse impact of fungicides on soil microbiome through the use of appropriate remediation methods, like, e.g., biostimulation, is of greater concern from the ecological perspective.
\end{abstract}

Keywords Biostimulation $\cdot$ Bird droppings $\cdot$ Compost $\cdot$ Contamination $\cdot$ Soil ecosystem $\cdot$ Tebuconazole

\section{Introduction}

The use of fungicides is a common practice in plant protection against fungal pathogens. As reported by Muñoz-Leoz et al. (2011) and Ye et al. (2018), only a few of these preparations fulfill their task, whereas the others penetrate to the environment and may pose a threat to the organisms other than fungi.

Responsible editor: Zhaohui Wang

Jadwiga Wyszkowska

jadwiga.wyszkowska@uwm.edu.pl

1 Department of Microbiology, University of Warmia and Mazury in Olsztyn, Plac Łódzki 3, 10-727 Olsztyn, Poland
Some fungicides may remain in the environment for a long time and therefore might be detected in the soil, bottom deposits as well as in surface and underground waters (Fang et al. 2016; Wang et al. 2017). However, the soil which has a direct contact with fungicides is the most exposed to their adverse effects. By pervading to soil, these preparations pose a threat to soil ecology and health status. They may disrupt the stability of soil ecosystem by, among other things, modifying the activity and structure of microorganisms, as well as the course of biochemical processes in the soil. This in turn has a huge impact on soil health and, consequently, on its proper functioning (Wang et al. 2016). Soil-colonizing microorganisms are responsible for the formation of soil humus and take part in biogeochemical cycles and in soil structure formation. Therefore, understanding the effect of fungicides on soil 
microbiome is an important issue in risk assessment upon their use. It is, however, difficult to predict a relationship between the chemical structure of a fungicide and its effect on the activity of soil microorganisms and enzymes. Some fungicides may stimulate the growth and development of microorganisms, while others may inhibit them (Lo 2010).

Tebuconazole is one of the most commonly used fungicides worldwide. It belongs to a group of triazole compounds which inhibit ergoesterol (an important constituent of the cellular membrane of fungi) through demethylation at the C-14 level. Considering its stability, mobility, and toxicity, it is claimed to be a hazardous substance ( $\mathrm{Li}$ et al. 2015). Its half-life in soil varies and ranges from 49 (Muñoz-Leoz et al. 2011) to 610 days (Strickland et al. 2004). According to Youness et al. (2018), it is additionally sparingly biodegradable. Tebuconazole may modify the metabolism of an organism and even cause its death (Strickland et al. 2004; Youness et al. 2018). This has been proved by impaired metabolic functions of Daphnia magna or by death of Piaractus mesopotamicus fish after tebuconazole application at a dose of $3.88 \mathrm{mg} \mathrm{dm}^{-3}$ water for 2 days (Sehnem et al. 2010). Its use in crop protection against fungal diseases may contribute to changes in the population of soil microorganisms. However, some microorganisms, like, e.g., Trichoderma harzianum, T. atroviride (Hatvani et al. 2006), Pseudomonas fluorescens, P. putida, Enterobacter sakazakii, Serratia sp. (Sehnem et al. 2010), and S. marcescens, exhibit a vast potential for its degradation in the soil environment (Wang et al. 2018).

The adverse effect of fungicides on the soil ecosystem may be minimized through the improvement of its general condition. This may be achieved by soil supplementation with appropriate microbiome-stimulating substances, like, e.g., compost or manure, which increase contents of nutrients and organic matter as well as improve water and air balance in the soil. They not only provide nutrients to the soil microorganisms but also improve the general condition of plants (D'Hose et al. 2012). Due to their high organic matter content and sorption capabilities, they may be used to remediate soil exposed to toxic substances. But even though they are commonly used to improve soil fertility, still little is known on their impact on the biological activity of soil contaminated with fungicides, tebuconazole in particular.

The successively increasing use of pesticides and their accidental penetration to the soil environment may lead to its serious transformations. These changes may be manifested by the impairment of the proper functions of soil ecosystems and by the loss of soil fertility which is largely determined by the soil-dwelling microorganisms (Fang et al. 2016; Bragança et al. 2019). The available scientific literature still lacks detailed information concerning the problem of risks posed by the use of fungicides and solutions proposed to restore the desired properties of soils degraded by these chemicals. Soil quality can be improved via different operations, one of which is its biostimulation with organic fertilizers (Pimmata et al. 2013) that may enhance proliferation of microorganisms exhibiting a high capability for fungicides degradation (Adams et al. 2015). This manuscript presents results of a study which allowed for estimating changes that had occurred in the soil environment under the effect of tebuconazole and for the evaluation of the efficacy of the biostimulating substances used to restore the stability of the soil environment. The in-depth analysis of the adverse effect of tebuconazole on soil environment required conducting a study which enabled precise evaluation of its impact on soil microbiota, biochemical process, and spring barley growth. It was also essential to undertake appropriate remediation measures which aimed at restoring soil stability through its fertilization with compost and bird droppings. Finally, analyses were carried out to evaluate the efficacy of these fertilizers in tebuconazole degradation in the soil.

\section{Materials and methods}

\subsection{Characteristics of the tested fungicide}

A growing pot experiment was conducted with a Helicur $250 \mathrm{EW}$ fungicide, containing tebuconazole as an active substance (250 $\mathrm{g} \mathrm{dm}^{-3}$ of agent) and belonging to a group of triazoles. The fungicide is produced by Helm AG company (Germany) and used in doses ranging from 0.75 to $1.0 \mathrm{dm}^{3} \mathrm{ha}^{-1}$. It is a systemic fungicide in the form of a liquid used to prepare a water emulsion for preventive and intervention treatments performed to protect winter wheat, spring barley, winter rape, sugar beet, and cherry. Tebuconazole characteristics are provided in Table 1.
Table 1 Selected properties of tebuconazole (PPDB-Pesticide Properties DataBase)

\begin{tabular}{|c|c|c|c|c|c|c|}
\hline \multirow[t]{2}{*}{ Fungicide } & \multirow[t]{2}{*}{ Chemical group } & \multirow{2}{*}{$\begin{array}{l}\log P \\
\text { at } \mathrm{pH} 7\end{array}$} & \multirow[t]{2}{*}{$\mathrm{p} K_{\mathrm{a}}$ values } & \multirow{2}{*}{$\begin{array}{l}\text { Water solubility } \\
\left(\mathrm{mg} \mathrm{dm}^{-3}\right)\end{array}$} & \multicolumn{2}{|c|}{$\mathrm{DT}_{50}$ (days) } \\
\hline & & & & & Typical & Field \\
\hline Tebuconazole & Triazole & 3.7 & 5.0 & 36 & 63 & 47.1 \\
\hline
\end{tabular}

$\log P$ - octanol-water partition coefficient at $20{ }^{\circ} \mathrm{C} ; \mathrm{p} K_{\mathrm{a}}$ - dissociation constant at $25^{\circ} \mathrm{C} ; \mathrm{DT}_{50}$ - half time in the soil 


\subsection{Characteristics of soil material}

The pot experiment was conducted with typical brown soil, classified in terms of its granulometric composition as loamy sand (WRB 2014). Soil samples were collected from the topsoil layer at the Experimental Station in Tomaszkowo located in north-eastern Poland $\left(53.7161^{\circ} \mathrm{N}, 20.4167^{\circ} \mathrm{E}\right)$. Their granulometric composition and selected physicochemical properties were determined according to methods described in a work by Borowik et al. (2017) and presented in Table 2.

\subsection{Characteristics of biostimulating substances}

Two organic biostimulating substances were used in the experiment, namely, compost and bird droppings. Compost was produced by Ekokonsorcjum-Effekt company (Cracow, Poland) from green waste (bunches, shrubs, grass) originating from private areas, parks, and green squares; crops (fruits, vegetables) collected from market squares; and organic waste collected from canteens and agri-food processing plants. Its composition was as follows: nitrogen, $1.3 \%$; phosphorus, $0.26 \%$; potassium, $1.18 \%$; magnesium, $0.30 \%$; calcium, $1.60 \%$; organic matter, $40.0 \%$; and dry matter, $35.0 \%$. Bird droppings were produced by PPHU CDN Polska company and were composed of organic matter, $98.27 \%$; nitrogen, $3.50 \%$; phosphorus, $3.45 \%$; and potassium, $1.70 \%$.

\subsection{Design of pot experiment}

The experiment was performed in six replications in a greenhouse, in $3.5-\mathrm{dm}^{3}$ polyethylene pots each filled with $2.7 \mathrm{~kg}$ of air dry soil. The soil used in the experiment was classified as loamy sand having $\mathrm{pH}_{\mathrm{KCl}} 5.6$; therefore, on the day of starting the experiment, $\mathrm{CaCO}_{3}$ was added to the soil in the amount equilibrating the hydrolytic acidity at the level of $1.5 \mathrm{Hh}$ to neutralize it. There were three experimental factors: factor Ifungicide dose $(0.000,0.042,0.083,0.125,1.249$, and $2.499 \mathrm{mg} \mathrm{kg}^{-1}$ ), factor II-type of the biostimulating substance (sample without the addition of biostimulating substance, compost in a dose of $10 \mathrm{~g} \mathrm{~kg}^{-1}$, and bird droppings in a dose of $3.71 \mathrm{~g} \mathrm{~kg}^{-1}$ ), and factor III- term of soil sample collection (days 20, 40, and 60 of the experiment). The dose of biostimulating substances was calculated based on nitrogen content. The following doses of fertilizers were used in the experiment (per pure compound in $1 \mathrm{~kg} \mathrm{DM}$ of soil): nitrogen in the form of phosphorus in the form of $\mathrm{KH}_{2} \mathrm{PO}_{4}-44 \mathrm{mg}$, potassium in the form of $\mathrm{KH}_{2} \mathrm{PO}_{4}+\mathrm{KCl}-100 \mathrm{mg}$, and magnesium in the form of $\mathrm{MgSO}_{4} \cdot 7 \mathrm{H}_{2} \mathrm{O}-25 \mathrm{mg}$. Fertilization with nitrogen in the form of $\mathrm{CO}\left(\mathrm{NH}_{2}\right)_{2}$ and in a dose of $130 \mathrm{mg} \mathrm{N} \mathrm{kg}^{-1} \mathrm{DM}$ of soil was used exclusively in the control series. The same dose of nitrogen was provided by compost and bird droppings. Once the appropriate doses of the fungicide and the biostimulating substance had been added to the soil, it was thoroughly homogenized and placed in the pots. Next, deionized water was used to bring the soil material to $50 \%$ of the capillary volume of water, which was maintained throughout the experiment. The crop used in the experiment was spring barley of 'Orphelia' cultivar. Microbiological and enzymatic analyses were conducted three times in the growing period of barley. On day 40 of the experiment, residues of tebuconazole were determined in soil samples to which Helicur 250 EW fungicide was added in doses of $0.083 \mathrm{mg} \mathrm{kg}^{-1}$ (optimal dose) and $2.499 \mathrm{mg} \mathrm{kg}^{-1}$ (30 times higher doses than the optimal dose), whereas on day 60 of the experiment, analyses were conducted for spring barley yield.

\subsection{Microbiological and enzymatic analyses of soil samples}

Microbiological and biochemical analyses of soil samples were carried out in triplicate in three time points of the experiment, with a 20-day interval (i.e., on days 20,40, and 60 of the experiment). Counts of organotrophic bacteria, actinobacteria, and fungi were determined with the method of serial dilutions. The composition of microbiological media was as provided in the work by Kucharski et al. (2016). Activities of enzymes representing oxidoreductases (dehydrogenases, catalase) and hydrolases (urease, acid phosphatase, alkaline phosphatase, $\beta$-glucosidase, arylsulfatase) were determined at each time point using the following substrates: dehydrogenases - $3 \%$ TTC, catalase - 3\% hydrogen peroxide, urease- $10 \%$ urea, acid and alkaline phosphatase - disodium 4-nitrophenylphosphate, $\beta$-glucosidase-4nitrophenyl- $\beta$-D-glucosidase, and arylsulfatase - potassium 4-nitrophenyl sulfate. Activities of soil enzymes were determined as described by Borowik et al. (2017).

Table 2 Granulometric composition and selected physicochemical properties of the soil used in the experiment

\begin{tabular}{|c|c|c|c|c|c|c|c|c|c|c|}
\hline \multirow[t]{2}{*}{ Soil } & \multicolumn{3}{|c|}{ Percentage content of fraction } & \multirow[t]{2}{*}{$\mathrm{pH}_{\mathrm{KCl}}$} & \multirow{2}{*}{$\begin{array}{l}\mathrm{C}_{\text {org }} \\
\mathrm{g} \mathrm{kg}^{-1}\end{array}$} & \multirow[t]{2}{*}{$\mathrm{N}_{\text {total }}$} & \multirow{2}{*}{\multicolumn{2}{|c|}{$\begin{array}{l}\text { HAC } \\
\mathrm{mM}(+) \mathrm{kg}^{-1}\end{array}$}} & \multirow[t]{2}{*}{ CEC } & \multirow{2}{*}{$\begin{array}{l}\mathrm{BS} \\
\%\end{array}$} \\
\hline & Sand $(2000-50 \mu \mathrm{m})$ & Silt $(50-2 \mu \mathrm{m})$ & Clay $(<2 \mu \mathrm{m})$ & & & & & & & \\
\hline Loamy sand (ls) & 80.50 & 18.00 & 1.50 & 5.6 & 10.0 & 0.58 & 18.66 & 40.00 & 58.00 & 68.96 \\
\hline
\end{tabular}

$\mathrm{pH}_{\mathrm{KCl}}$ - soil reaction; $\mathrm{C}_{\mathrm{org}}$ —organic carbon content; $\mathrm{N}_{\text {total }}$ - total nitrogen content; HAC—hydrolytic acidity; TEB — sum of exchangeable bases; CEC — sorption capacity; BS - base saturation 


\subsection{Determination of tebuconazole residues in the soil}

Residues of tebuconazole in the soil were determined with the QuEChERS method using a liquid chromatography system (Eksigent Technologies, Dublin, CA, USA) coupled with a 6500 QTRAP mass spectrometer (AB Sciex Instruments, Foster City, CA) according to the method described by Kaczyński (2017). Tebuconazole detection limit was $0.005 \mathrm{mg} \mathrm{kg}^{-1}$, analytical recovery value accounted for $92 \%$, whereas retention time was $27.44 \mathrm{~min}$.

\subsection{Determination of spring barley yield}

Twenty-five grains of spring barley were sown into each pot. Once they had sprouted, thinning was performed and 12 plants were left in each pot. Spring barley dry matter yield was determined after plant harvest on day 60 , at the end of the heading stage (BBCH 59 developmental stage, completely visible head).

\subsection{Computations and statistical analysis}

Relative changes $(R C h)$ in the counts of microorganisms and in activities of enzymes in the soil exposed to tebuconazole expressed in percentages were computed according to the formula provided by Chaer et al. (2009):

$R C h=\left(\frac{\mathrm{T}}{\mathrm{C}}-1\right) \cdot 100$

where $T$ - mean count of microorganisms/enzyme activity in the soil exposed to tebuconazole and $C$-mean count of microorganisms/enzyme activity in the control soil.

The determined activities of soil enzymes allowed computing the biochemical index of soil quality $\left(\mathrm{BA}_{21}\right)$ according to the formula proposes by Wyszkowska et al. (2013a):

$\mathrm{BA}=\mathrm{Deh}+\mathrm{Cat}+\mathrm{Ure}+\mathrm{Pac}+\mathrm{Pal}+\mathrm{Glu}+\mathrm{Aryl}$

where Deh - activity of dehydrogenases ( $\mu \mathrm{mol} \mathrm{TFF} \mathrm{kg}{ }^{-1} \mathrm{DM}$ soil $\left.\mathrm{h}^{-1}\right)$, Cat - activity of catalase $\left(\mathrm{mol} \mathrm{O}_{2} \mathrm{~kg}^{-1} \mathrm{DM}\right.$ soil h $\left.\mathrm{h}^{-1}\right)$, Ure-activity of urease (mmol N-NH $\mathrm{kg}^{-1} \mathrm{DM}$ soil h $\left.\mathrm{h}^{-1}\right)$, Pac - activity of acid phosphatase (mmol PNP kg-1 DM soil $\mathrm{h}^{-1}$ ), Pal - activity of alkaline phosphatase (mmol PNP kg${ }^{-1}$ DM soil $\mathrm{h}^{-1}$ ), Glu —activity of $\beta$-glucosidase (mmol PNP $\mathrm{kg}^{-1} \mathrm{DM}$ soil $\mathrm{h}^{-1}$ ), and Aryl - activity of arylsulfatase (mmol PNP kg ${ }^{-1}$ DM soil h${ }^{-1}$ ).

The index of the effect of biostimulating substances $\left(\mathrm{IF}_{\mathrm{C} / \mathrm{BD}}\right)$ on the proliferation of microorganisms and on the activity of soil enzymes was calculated using the formula provided in a work by Kaczyńska et al. (2015):

$\mathrm{IF}_{\mathrm{C} / \mathrm{BD}}=\frac{\mathrm{A}_{\mathrm{C} / \mathrm{BD}}}{\mathrm{A}}$ where $C$-compost, $B D$ - bird droppings, $A_{C / B D}$-count of microorganisms/enzyme activity in the soil with the addition of biostimulating substances, and $A$-count of microorganisms/enzyme activity in the soil without the addition of biostimulating substances.

The index of spring barley resistance (RS) to tebuconazole was computed according to the formula described by Orwin and Wardle (2004):

$\mathrm{RS}=1-\frac{2\left|\mathrm{D}_{0}\right|}{\mathrm{C}_{0}+\left|\mathrm{D}_{0}\right|}$

where $D_{0}$-difference between the control soil sample $\left(C_{0}\right)$ and the soil sample exposed to tebuconazole $\left(P_{0}\right)$. Values of the RS index range from -1 to 1 . When they fall between -1 and 0 , they are indicative of the negative effect of tebuconazole, whereas when they approximate 1 , they are indicative of higher resistance.

Results were developed statistically with the analysis of variance (ANOVA) at a significance level of $P \leq 0.05$ using STATISTICA 13.1 software (2018). The $\eta^{2}$ coefficient was used to calculate the percentage of the observed variability for the counts of microorganisms and activities of soil enzymes. Homogeneous groups were determined using Tukey's test (HSD). The responses of microorganisms to tebuconazole were presented as a Ward dendrogram using cluster analysis (CA). In turn, the principal component analysis (PCA) of the activity of enzymes in the soil contaminated with tebuconazole was performed using a multidimensional exploratory technique.

\section{Results and discussion}

\subsection{Microbiological properties of soil}

Soil represents a suitable environment for living organisms, microorganisms in particular, which are responsible for various processes, including the circuit of nutrients or energy transfer. Hence, their presence is indispensable for ensuring and sustaining the proper functions of soil ecosystems (Swędrzyńska and Małecka-Jankowiak 2017). However, these favorable conditions may be disturbed by, e.g., stress posed by the appearance of toxic substances which can be harmful to microorganisms (Nowak et al. 2013; Xu et al. 2018). According to Wang et al. (2012), fungicides may trigger significant changes in the proliferation of microorganisms as well as in their structure and diversity. Adverse effects of fungicides on soil microbiome are usually reported after their application in doses several times higher from their optimal dose. The statistical analysis conducted in our study demonstrated that the type of the biostimulating substance had the strongest impact on soil microbiome structure (Fig. 1). The 
Fig. 1 Percentage of the observed variability $\left(\eta^{2}\right)$ in the soil contaminated with tebuconazole (\%). Org - organotrophic bacteria; Act —actinobacteria; Fun-fungi; Dehdehydrogenases; Cat — catalase; Ure - urease; Pac - acid phosphatase; $\mathrm{Pal}$ —alkaline phosphatase; Glu- $\beta$ glucosidase; Aryl — arylsulfatase; DF - dose of tebuconazole, SB type of biostimulating substances, $\mathrm{T}$ - date of analysis

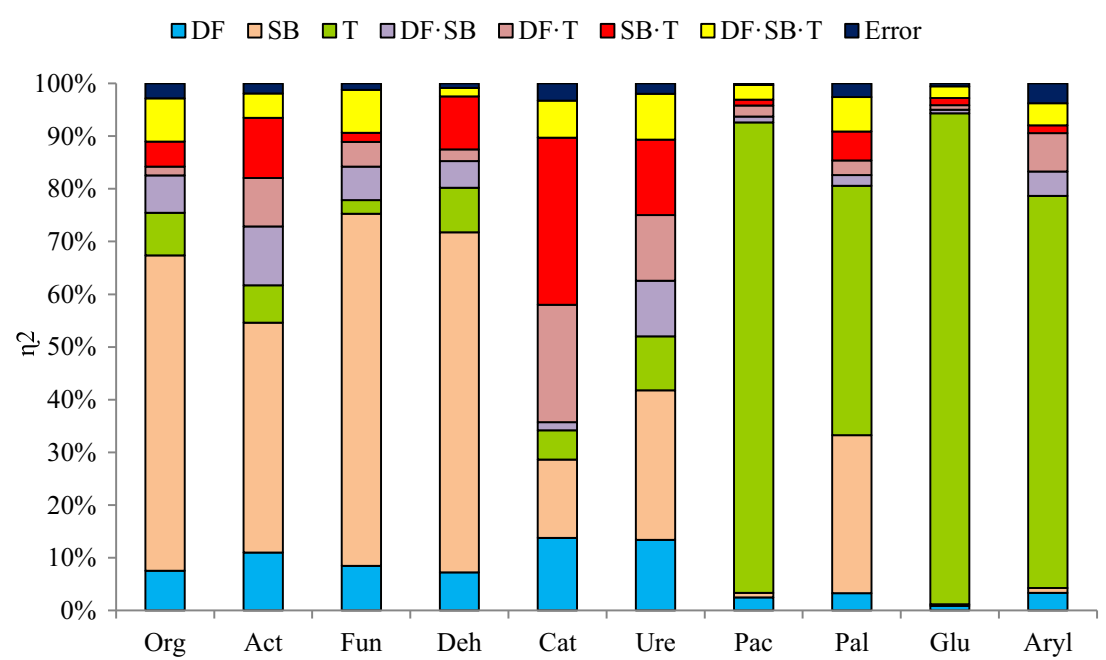

effect of tebuconazole on microorganisms proliferation varied depending on its dose and retention time in the soil (Table 3). On day 20 of the experiment, the organotrophic bacteria responded to soil treatment with tebuconazole in doses of $1.249 \mathrm{mg} \mathrm{kg}^{-1}$ and $2.499 \mathrm{mg} \mathrm{kg}^{-1}$ by a decrease in their population count. In turn, on days 40 and 60, tebuconazole administered to the soil in doses from $0.042 \mathrm{mg} \mathrm{kg}^{-1}$ to $2.499 \mathrm{mg} \mathrm{kg}^{-1}$ stimulated proliferation of these bacteria. The response of actinobacteria to tebuconazole present in the soil was slightly different. On days 20 and 40 of the experiment, the fungicide had a stimulating effect on actinobacteria population when used in doses from $0.042 \mathrm{mg} \mathrm{kg}^{-1}$ to $1.249 \mathrm{mg} \mathrm{kg}^{-1}$, whereas on day 60 , such an effect was observed only upon soil treatment with tebuconazole in doses of $0.042 \mathrm{mg} \mathrm{kg}^{-1}$ and $0.083 \mathrm{mg} \mathrm{kg}^{-1}$. Among the analyzed groups of microorganisms, fungi turned out to be the most susceptible to the effects of the tested fungicide. On day 20 of experiment, the development of fungi was significantly inhibited by tebuconazole doses from
$0.083 \mathrm{mg} \mathrm{kg}^{-1}$ to $2.499 \mathrm{mg} \mathrm{kg}^{-1}$, on day 40 - by tebuconazole dose of $2.499 \mathrm{mg} \mathrm{kg}^{-1}$, whereas on day 60 - by its doses from $0.125 \mathrm{mg} \mathrm{kg}^{-1}$ to $2.499 \mathrm{mg} \mathrm{kg}^{-1}$. Figure 2 presents a dendrogram plotted with the Ward method to depict the response of microorganisms to soil contamination with tebuconazole. Two groups of microorganisms were distinguished whose responses to the applied doses of the fungicide were similar. The first group included fungi which were more susceptible to the effect of tebuconazole, whereas the second group was represented by organotrophs and actinobacteria, which proves their similar response to the tested preparation. The effect of tebuconazole on the growth of soil microorganisms was also depicted via the $R C h$ index (Fig. 3). Its mean values demonstrated that tebuconazole inhibited the proliferation of actinobacteria and fungi. Consequently, the decrease in actinobacteria count ranged from $5.71 \%$ (dose $1.249 \mathrm{mg} \mathrm{kg}^{-1}$ ) to $37.25 \%$ (dose $2.499 \mathrm{mg} \mathrm{kg}^{-1}$ ), and that of fungi count from $2.12 \%$ (dose $0.125 \mathrm{mg} \mathrm{kg}^{-1}$ ) to $36.81 \%$ (dose $2.499 \mathrm{mg} \mathrm{kg}^{-1}$ ) compared to the control sample. Some authors

Table 3 Counts of microorganisms in the soil contaminated with tebuconazole, $\log \mathrm{cfu} \mathrm{kg}^{-1} \mathrm{DM}$ of soil

\begin{tabular}{|c|c|c|c|c|c|c|c|c|c|}
\hline \multirow{3}{*}{$\begin{array}{l}\text { Dose of Te } \\
\mathrm{mg} \mathrm{kg}^{-1}\end{array}$} & \multicolumn{3}{|l|}{ Org } & \multicolumn{3}{|l|}{ Act } & \multicolumn{3}{|l|}{ Fun } \\
\hline & \multicolumn{9}{|c|}{ Date of analysis (days) } \\
\hline & 20 & 40 & 60 & 20 & 40 & 60 & 20 & 40 & 60 \\
\hline 0.000 & $2.184^{\mathrm{b}}$ & $1.955^{\mathrm{de}}$ & $1.892^{\mathrm{f}}$ & $2.048^{\mathrm{h}}$ & $2.393^{\mathrm{ab}}$ & $2.379^{\mathrm{ab}}$ & $1.530^{\mathrm{efg}}$ & $1.599^{\text {cde }}$ & $1.659^{\mathrm{abc}}$ \\
\hline 0.042 & $2.193^{\mathrm{b}}$ & $2.102^{\mathrm{bc}}$ & $2.012^{\text {de }}$ & $2.185^{\mathrm{f}}$ & $2.423^{\mathrm{a}}$ & $2.382^{\mathrm{ab}}$ & $1.574^{\mathrm{def}}$ & $1.650^{\mathrm{abc}}$ & $1.625^{\mathrm{cd}}$ \\
\hline 0.083 & $2.286^{\mathrm{a}}$ & $2.102^{\mathrm{bc}}$ & $2.033^{\mathrm{d}}$ & $2.206^{\mathrm{e}}$ & $2.428^{\mathrm{a}}$ & $2.375^{\mathrm{ab}}$ & $1.512^{\mathrm{fg}}$ & $1.713^{\mathrm{a}}$ & $1.714^{\mathrm{a}}$ \\
\hline 0.125 & $2.285^{\mathrm{a}}$ & $2.271^{\mathrm{ab}}$ & $2.166^{\mathrm{c}}$ & $2.150^{\mathrm{f}}$ & $2.401^{\mathrm{ab}}$ & $2.318^{\mathrm{bc}}$ & $1.481^{\mathrm{gh}}$ & $1.676^{\mathrm{ab}}$ & $1.588^{\mathrm{def}}$ \\
\hline 1.249 & $2.065^{\mathrm{cd}}$ & $2.091^{\mathrm{cd}}$ & $1.999^{\text {de }}$ & $2.145^{\mathrm{fg}}$ & $2.298^{\mathrm{c}}$ & $2.269^{\mathrm{d}}$ & $1.466^{\mathrm{gh}}$ & $1.551^{\mathrm{ef}}$ & $1.489^{\mathrm{gh}}$ \\
\hline 2.499 & $1.878^{\mathrm{f}}$ & $2.083^{\mathrm{cd}}$ & $1.993^{\text {de }}$ & $1.966^{\mathrm{g}}$ & $2.106^{\mathrm{g}}$ & $2.111^{\mathrm{g}}$ & $1.463^{\mathrm{gh}}$ & $1.298^{\mathrm{j}}$ & $1.389^{\mathrm{i}}$ \\
\hline Average & 2.149 & 2.101 & 2.016 & 2.117 & 2.342 & 2.306 & 1.504 & 1.581 & 1.577 \\
\hline$r$ & -0.949 & -0.068 & -0.129 & -0.702 & -0.986 & -0.975 & -0.687 & -0.944 & -0.935 \\
\hline
\end{tabular}

Homogenous groups denoted with letters $(\mathrm{a}-\mathrm{h})$ were calculated separately for each group of microorganisms

Te — tebuconazole; Org — organotrophic bacteria; Act—actinobacteria; Fun—fungi; $r$-Pearson's correlation coefficient 
Fig. 2 Response of microorganisms to tebuconazole. Org — organotrophic bacteria; Act - actinobacteria; Fun - fungi. Date of analysis: $20-20$ days, 40 40 days, $60-60$ days

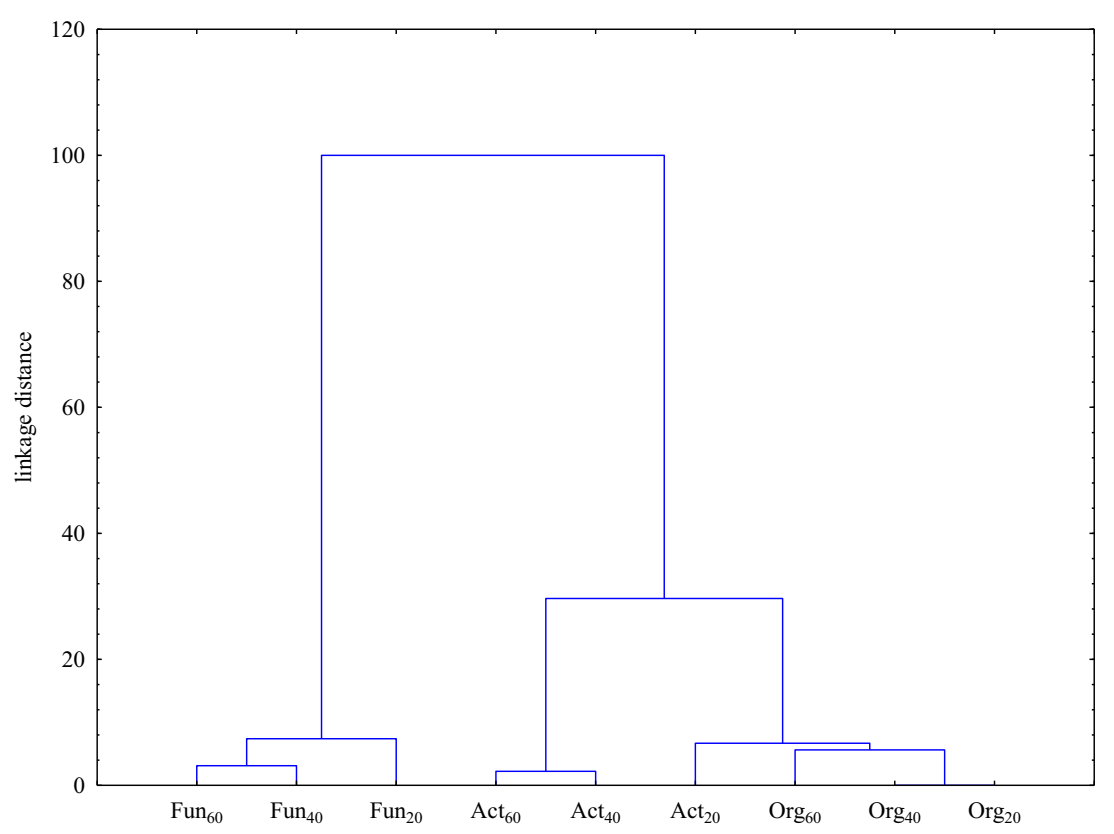

(García-Gil et al. 2013; Mohiuddin and Mohammed 2013; Saha et al. 2016) claim that excess amounts of fungicides in the soil may negatively affect its microbiome by inhibiting microorganism growth. A fine example in this case is the study conducted by Guo et al. (2015) with azoxystrobin, which demonstrated decreased counts of bacteria, actinobacteria, and fungi after soil exposure to its doses of 1.0 and $10.0 \mathrm{mg} \mathrm{kg}^{-1}$. Our previous study (Baćmaga et al. 2018) demonstrated stimulated proliferation of organotrophic bacteria and actinobacteria in the soil contaminated with chlorothalonil (doses from 0.166 to $16.60 \mathrm{mg} \mathrm{kg}^{-1}$ ). Then, Wu et al. (2015) reported the effect of fungicides on soil microorganism proliferation to be usually short lasting. This has been proved in their study which aimed to determine the effect of fluxapyroxad introduced to the soil in doses from 0.75 to $75 \mathrm{mg} \mathrm{kg}^{-1}$ on the biomass of microorganisms, soil respiration, and structure of bacterial populations. In turn, Ahemad and Khan (2012) investigated the effect of four fungicides (tebuconazole, hexaconazole, metalaxyl, and kitazin) on the growth and activity of Pseudomonas putida bacteria under in vitro conditions. Their optimal doses and their two to three times higher doses inhibited $P$. putida development. Tebuconazole turned out to be the most toxic among them.
To neutralize the adverse effect of tebuconazole on soil microorganisms, the soil was remediated with the biostimulation method. The effect of biostimulating substances (compost and bird droppings) on its microbiological properties was analyzed based on the $\mathrm{IF}_{\mathrm{C} / \mathrm{BD}}$ index (Table 4), which indicates soil environment condition and changes occurring in it by the biostimulants (Kaczyńska et al. 2015). Values of the $\mathrm{IF}_{\mathrm{C} / \mathrm{BD}}$ index achieved in our study point to the varied effects of compost and bird droppings on soil fertility improvement. Bird droppings turned out to be an effective biostimulant of the growth of all soil microorganisms tested, and especially of fungi (Table 4). Regardless of tebuconazole doses, the mean value of $\mathrm{IF}_{\mathrm{C} / \mathrm{BD}}$ index was 1.772 for organotrophic bacteria, 1.152 for actinobacteria, and 3.032 for fungi. Bird droppings introduced to the soil contaminated with tebuconazole dose of $2.499 \mathrm{mg} \mathrm{kg}^{-1}$ had a positive impact on the growth of microorganisms by providing desired nutrients and by ensuring conditions which facilitated their growth and development (Hale and Fawy 2011). In the soil supplemented with bird droppings and exposed to this dose of tebuconazole, the value of $\mathrm{IF}_{\mathrm{C} / \mathrm{BD}}$ index reached 2.129 for
Fig. 3 Relative changes $R C h(\%)$ in the proliferation of microorganisms in the soil contaminated with tebuconazole. $\mathrm{Te}$ - tebuconazole; Orgorganotrophic bacteria; Actactinobacteria; Fun - fungi. Homogenous groups denoted with letters $(\mathrm{a}-\mathrm{e})$ were calculated separately for each group of microorganisms

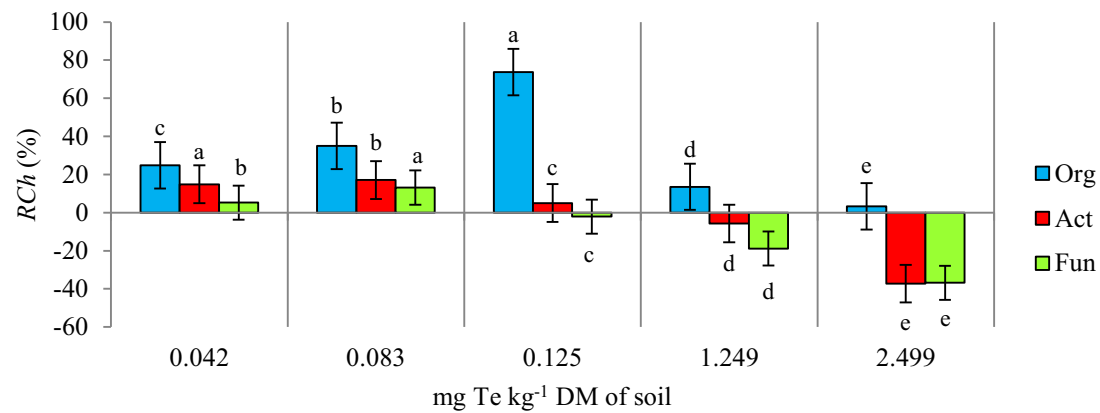


Table 4 Index of the effect of biostimulating substances $\left(\mathrm{IF}_{\mathrm{C} / \mathrm{BD}}\right)$ on the proliferation of soil microorganisms

\begin{tabular}{|c|c|c|c|c|c|c|c|c|c|}
\hline \multirow{3}{*}{$\begin{array}{l}\text { Dose of Te } \\
\mathrm{mg} \mathrm{kg}^{-1}\end{array}$} & \multicolumn{3}{|l|}{ Org } & \multicolumn{3}{|l|}{ Act } & \multicolumn{3}{|l|}{ Fun } \\
\hline & \multicolumn{9}{|c|}{ Date of analysis (days) } \\
\hline & 20 & 40 & 60 & 20 & 40 & 60 & 20 & 40 & 60 \\
\hline \multicolumn{10}{|l|}{ Compost } \\
\hline 0.000 & $0.552^{\mathrm{fg}}$ & $1.503^{\mathrm{a}}$ & $1.570^{\mathrm{a}}$ & $0.954^{\mathrm{b}}$ & $0.437^{\mathrm{f}}$ & $0.559^{\mathrm{e}}$ & $1.205^{\mathrm{d}}$ & $0.667^{\mathrm{g}}$ & $0.991^{\mathrm{e}}$ \\
\hline 0.042 & $0.666^{\mathrm{e}}$ & $0.975^{\mathrm{c}}$ & $1.062^{\mathrm{c}}$ & $0.814^{\mathrm{c}}$ & $0.514^{\mathrm{ef}}$ & $0.525^{\mathrm{e}}$ & $1.246^{\mathrm{cd}}$ & $0.662^{\mathrm{g}}$ & $1.237^{\mathrm{cd}}$ \\
\hline 0.083 & $0.580^{\mathrm{f}}$ & $0.957^{\mathrm{c}}$ & $0.993^{\mathrm{c}}$ & $0.835^{\mathrm{c}}$ & $0.488^{\mathrm{f}}$ & $0.533^{\mathrm{e}}$ & $1.482^{\mathrm{ab}}$ & $0.729^{\mathrm{f}}$ & $1.247^{\mathrm{cd}}$ \\
\hline 0.125 & $0.589^{f}$ & $0.566^{\mathrm{f}}$ & $0.671^{\mathrm{e}}$ & $0.914^{\mathrm{b}}$ & $0.472^{\mathrm{f}}$ & $0.567^{\mathrm{e}}$ & $1.333^{\mathrm{c}}$ & $0.720^{\mathrm{f}}$ & $1.524^{\mathrm{a}}$ \\
\hline 1.249 & $0.927^{\mathrm{cd}}$ & $0.839^{\mathrm{d}}$ & $0.956^{\mathrm{c}}$ & $0.957^{\mathrm{b}}$ & $0.519^{\mathrm{ef}}$ & $0.526^{\mathrm{e}}$ & $1.377^{\mathrm{c}}$ & $0.901^{\mathrm{e}}$ & $1.543^{\mathrm{a}}$ \\
\hline 2.499 & $1.404^{\mathrm{b}}$ & $0.827^{\mathrm{d}}$ & $0.930^{\mathrm{cd}}$ & $1.127^{\mathrm{a}}$ & $0.779^{\mathrm{d}}$ & $0.764^{\mathrm{d}}$ & $1.069^{\mathrm{e}}$ & $1.419^{\mathrm{ab}}$ & $1.668^{\mathrm{a}}$ \\
\hline Average & 0.786 & 0.945 & 1.030 & 0.934 & 0.535 & 0.579 & 1.285 & 0.850 & 1.368 \\
\hline$r$ & 0.990 & -0.298 & -0.259 & 0.873 & 0.922 & 0.828 & -0.553 & 0.979 & 0.756 \\
\hline \multicolumn{10}{|c|}{ Bird droppings } \\
\hline 0.000 & $1.196^{\mathrm{g}}$ & $2.152^{\mathrm{c}}$ & $2.098^{\mathrm{c}}$ & $1.490^{\mathrm{b}}$ & $0.622^{\mathrm{f}}$ & $0.746^{\mathrm{de}}$ & $6.187^{\mathrm{a}}$ & $1.963^{\mathrm{g}}$ & $2.369^{\mathrm{e}}$ \\
\hline 0.042 & $1.232^{\mathrm{f}}$ & $1.575^{\mathrm{d}}$ & $1.673^{\mathrm{d}}$ & $1.086^{\mathrm{d}}$ & $0.797^{\text {de }}$ & $0.863^{\mathrm{d}}$ & $3.284^{\mathrm{c}}$ & $3.034^{\mathrm{c}}$ & $3.972^{\mathrm{b}}$ \\
\hline 0.083 & $1.197^{\mathrm{g}}$ & $1.924^{\mathrm{c}}$ & $1.622^{\mathrm{d}}$ & $1.334^{\mathrm{bc}}$ & $0.847^{\mathrm{d}}$ & $1.005^{\mathrm{d}}$ & $3.476^{\mathrm{c}}$ & $2.144^{\mathrm{f}}$ & $2.990^{\mathrm{d}}$ \\
\hline 0.125 & $1.503^{\mathrm{d}}$ & $1.597^{\mathrm{d}}$ & $1.195^{\mathrm{g}}$ & $1.588^{\mathrm{a}}$ & $0.941^{\mathrm{d}}$ & $1.104^{\mathrm{d}}$ & $2.702^{\mathrm{d}}$ & $2.117^{\mathrm{f}}$ & $3.410^{\mathrm{c}}$ \\
\hline 1.249 & $2.758^{\mathrm{b}}$ & $1.979^{\mathrm{c}}$ & $1.811^{\mathrm{d}}$ & $1.677^{\mathrm{a}}$ & $1.172^{\mathrm{c}}$ & $1.170^{\mathrm{c}}$ & $2.708^{\mathrm{d}}$ & $2.407^{\mathrm{e}}$ & $3.282^{\mathrm{c}}$ \\
\hline 2.499 & $3.474^{\mathrm{a}}$ & $1.367^{\mathrm{e}}$ & $1.548^{\mathrm{d}}$ & $1.670^{\mathrm{a}}$ & $1.331^{\mathrm{bc}}$ & $1.296^{\mathrm{c}}$ & $1.965^{\mathrm{g}}$ & $3.189^{\mathrm{c}}$ & $3.382^{\mathrm{c}}$ \\
\hline Average & 1.893 & 1.766 & 1.658 & 1.474 & 0.952 & 1.031 & 3.387 & 2.476 & 3.234 \\
\hline$r$ & 0.982 & -0.493 & -0.095 & 0.625 & 0.916 & 0.813 & -0.600 & 0.630 & 0.171 \\
\hline
\end{tabular}

Homogenous groups denoted with letters $(\mathrm{a}-\mathrm{g})$ were calculated separately for each group of microorganisms and each type of biostimulating substance $\mathrm{Te}$ - tebuconazole; Org—organotrophic bacteria; Act—actinobacteria; Fun—fungi; $r$-Pearson's correlation coefficient

organotrophic bacteria, 1.432 for actinobacteria, and 2.845 for fungi. The enhanced microorganism proliferation after soil supplementation with bird droppings may be due to a high content of organic matter in this biostimulant $(98.27 \%)$, which stimulated their growth and development by providing desired nutrients. In addition, the organic matter could absorb tebuconazole from the soil and thereby minimize its adverse effect on microorganisms. In turn, compost was not that effective as bird droppings were. Its addition to the soil caused the $\mathrm{IF}_{\mathrm{C} / \mathrm{BD}}$ value to decrease below 1 in the case of actinobacteria (mean value of $\mathrm{IF}_{\mathrm{C} / \mathrm{BD}}=0.683$ ). Compost was also poorly effective in stimulating the growth of fungi (mean value of $\mathrm{IF}_{\mathrm{C} / \mathrm{BD}}=$ 1.168) and had no significant effect upon organotrophic bacteria (mean value of $\mathrm{IF}_{\mathrm{C} / \mathrm{BD}}=0.920$ ). Similar observations were made for the soil contaminated with tebuconazole dose of $2.499 \mathrm{mg} \mathrm{kg}^{-1}$. Mean values of the $\mathrm{IF}_{\mathrm{C} / \mathrm{BD}}$ index reached 1.054 for organotrophic bacteria, 0.890 for actinobacteria, and 1.385 for fungi. The effect of fertilizing substances on the microbiological properties of soil treated with chlorothalonil was evaluated in our previous study (Baćmaga et al. 2018), which demonstrated positive effects of Lignohumat Super and Bioilsa N 12.5 preparations on the growth of organotrophs, actinobacteria, and fungi, with Bioilsa N 12.5 appearing more useful in increasing soil fertility.

\subsection{Activity of soil enzymes}

Next to microorganisms, soil enzymes are claimed to be biomarkers of the soil environment contaminated with toxic substances, including fungicides (Sanchez-Hernandez et al. 2017). However, soil enzymes response to the administered fungicides may vary from either enhancement or suppression of their activity (Riah et al. 2014). Considering experimental factors analyzed in the present study, the type of the biostimulating substance had the strongest effect on activities of dehydrogenases and urease; the time point of analyses on the activities of acid phosphatase, alkaline phosphatase, $\beta$-glucosidase, and arylsulfatase; whereas the interaction of the biostimulating substance and time point of analysis - on the activity of catalase (Fig. 1). The principal component analysis demonstrated that soil contamination with tebuconazole caused significant changes in its biochemical activity (Fig. 4). The first principal component PCA1, which explained $47.72 \%$ of the total variability of data, represented activities of acid phosphatase, alkaline phosphatase, $\beta$-glucosidase, and arylsulfatase. The second principal component 
Fig. 4 Activity of enzymes in the soil contaminated with tebuconazole (PCA method). Deh - dehydrogenases; Catcatalase; Ure - urease; Pac - acid phosphatase; $\mathrm{Pal}$ —alkaline phosphatase; Glu - $\beta$ glucosidase; Aryl - arylsulfatase. Dose of tebuconazole $\left(\mathrm{mg} \mathrm{kg}^{-1}\right.$ DM of soil): $0-0.000,1-0.042$, $2-0.083,3-0.125,4-1.249$, 5-2.499. Date of analysis: A20 days, B-40 days, C-60 days

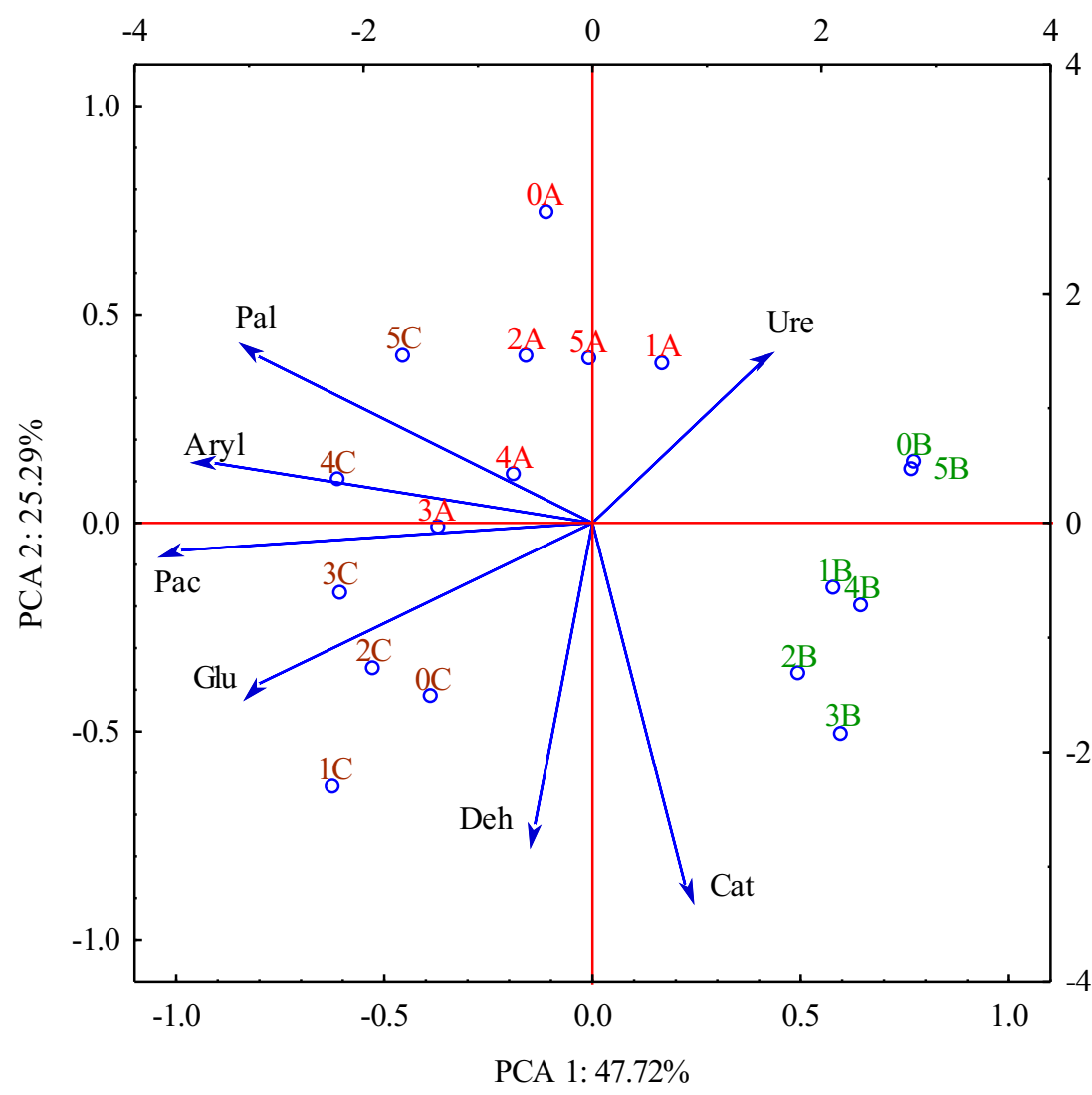

\begin{tabular}{cccccccc}
\hline Factors & Deh & Cat & Ure & Pac & Pal & Glu & Aryl \\
\hline PCA1 & -0.138 & 0.222 & 0.422 & -0.989 & -0.803 & -0.802 & -0.909 \\
PCA2 & -0.725 & -0.866 & 0.401 & -0.066 & 0.400 & -0.386 & 0.144 \\
\hline
\end{tabular}

PCA2, which explained $25.29 \%$ of the total variance, indicated activities of dehydrogenases, catalase, and urease. The PCA1 was negatively correlated with activities of dehydrogenases $(-0.138)$, acid phosphatase $(-0.989)$, alkaline phosphatase $(-0.803), \beta$-glucosidase $(-0.802)$, and arylsulfatase ($0.909)$, whereas PCA2 - with activities of dehydrogenases ($0.725)$, catalase $(-0.866)$, acid phosphatase $(-0.066)$, and $\beta-$ glucosidase $(-0.386)$. Values of the $R C h$ index showed that tebuconazole had the strongest inhibiting effect on the activity of urease (Fig. 5); its activity suppression ranged from $4.03 \%$ (at a dose of $0.042 \mathrm{mg} \mathrm{kg}^{-1}$ ) to $57.92 \%$ (at a dose of $2.499 \mathrm{mg} \mathrm{kg}^{-1}$ ). Alkaline phosphatase activity suppressed after soil contamination with tebuconazole dose of $0.125 \mathrm{mg} \mathrm{kg}^{-1}$ (activity suppression by $11.38 \%$ ); however, the greatest changes were elicited by its $2.499 \mathrm{mg} \mathrm{kg}^{-1}$ dose (activity decrease by $20.83 \%$ ). Tebuconazole dose of $2.499 \mathrm{mg} \mathrm{kg}^{-1}$ had an inhibiting effect on dehydrogenases (activity suppression by $17.44 \%$ ), arylsulfatase (activity suppression by $19.44 \%$ ), $\beta$-glucosidase (activity suppression by $8.54 \%$ ), and catalase (activity suppression by $4.55 \%$ ). Saha et al. (2016) also demonstrated the inhibiting effect of tebuconazole applied in doses of $375 \mathrm{~g} \mathrm{ha}^{-1}$ and $1875 \mathrm{~g} \mathrm{ha}^{-1}$ on the activity of such soil enzymes as dehydrogenases and nitrate reductase. In turn, Muñoz-Leoz et al. (2011) reported activity suppression of the four analyzed enzymes, i.e., arylsulfatase, $\beta$-glucosidase, alkaline phosphatase, and urease, after tebuconazole application in doses from 5 to $500 \mathrm{mg} \mathrm{kg}^{-1}$. Sanchez-Hernandez et al. (2017) also demonstrated soil enzymes to be very sensitive to pesticides. They reported a strong inhibiting effect of chlorpiryfos (at doses of 4.8 and $24.0 \mathrm{~kg} \mathrm{ha}^{-1}$ ) administered to soil belonging to Andisols on the activities of hydrolases (carboxyesterase, acid phosphatase, and $\beta$-glucosidase) and oxidoreductases (dehydrogenases and catalase). But still, the most sensitive turned out to be carboxyesterases whose activities decreased by $62 \%$ and $78 \%$, respectively. Sułowicz and PiotrowskaSeget (2016) tested effects of tetraconazole used in a dose recommended by the producer and in 10 times higher dose on the hydrolyzing activity of fluorescein diacetate (FDA) in the soil of grasslands and orchards. They observed suppressed 


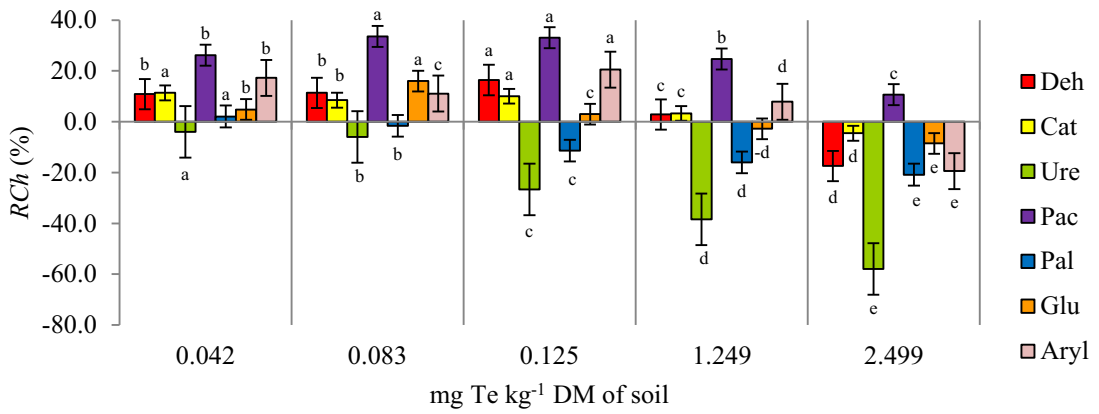

Fig. 5 Relative changes $R C h(\%)$ in the activity of enzymes in the soil contaminated with tebuconazole. Te-tebuconazole; Deh-dehydrogenases; Cat—catalase; Ure — urease; Pac — acid phosphatase; Pal— alkaline phosphatase; Glu- $\beta$-glucosidase; Aryl—arylsulfatase. Homogenous groups denoted with letters $(\mathrm{a}-\mathrm{e})$ were calculated separately for each enzyme activity of FDA in the soil of grasslands after tetraconazole administration in a dose being 10 times higher than recommended. In the case of the soil from orchards that was treated with tetraconazole, its total microbiological activity remained unchanged as compared to the control soil.

The negative effects of fungicides on the biochemical properties of soil may be minimized via appropriate treatments which promote the growth and development of microorganisms. The biostimulation process is one of such treatments as it provides desired nutrients to microorganisms from compost (Strachel et al. 2017; Wyszkowska et al. 2013b), manure (Wyszkowska et al. 2013b), straw (Baćmaga et al. 2012; Wyszkowska et al. 2013b), cellulose, tree bark (Boros et al. 2011; Wyszkowska et al. 2013b), or keratin (Boros et al. 2011). In our study, soil amendment with the biostimulating substances had a significant effect on its biochemical properties (Table 5). Mean values of the $\mathrm{IF}_{\mathrm{C} / \mathrm{BD}}$ index demonstrated that bird droppings stimulated activities of dehydrogenases $\left(\mathrm{IF}_{\mathrm{C} / \mathrm{BD}}=1.611\right)$, catalase $\left(\mathrm{IF}_{\mathrm{C} / \mathrm{BD}}=1.148\right)$, alkaline phosphatase $\left(\mathrm{IF}_{\mathrm{C} / \mathrm{BD}}=2.149\right)$, and arylsulfatase $\left(\mathrm{IF}_{\mathrm{C} / \mathrm{BD}}=1.134\right)$, and that compost had the strongest stimulating effect on alkaline phosphatase $\left(\mathrm{IF}_{\mathrm{C} / \mathrm{BD}}=1.325\right)$. The biostimulating substances turned out ineffective in the case of urease, as $\mathrm{IF}_{\mathrm{C} / \mathrm{BD}}$ value computed for this enzyme decreased significantly to 0.499 and 0.808 after soil supplementation with both compost and bird droppings, respectively. In the soil exposed to tebuconazole dose of $2.499 \mathrm{mg} \mathrm{kg}^{-1}$, both compost and bird droppings enhanced activities of dehydrogenases, catalases, alkaline phosphatase, acid phosphatase, and arylsulfatase. The enhancement of the activity of some enzymes elicited by soil treatment with biostimulating substances may be due to their organic substances which serve a protective function against soil enzymes. They immobilize them, as a result of which the enzymes become more stable and more resistant to stress conditions in the soil environment (Banach-Szott et al. 2014). Literature data concerning the effect of organic substances on the biochemical properties of pesticide-treated soil is scarce. When evaluating the effectiveness of organic substances (i.e., manure, slurry, vermicompost, mushroom compost) in enhancing activities of dehydrogenases in the soil contaminated with chlorpiryfos, Kadian et al. (2012) demonstrated that vermicompost and mushroom compost had the greatest potential in alleviating its adverse outcomes. Our previous study (Baćmaga et al. 2012) showed spring barley straw to be very effective in restoring the biochemical homeostasis of soil contaminated with carfentrazone herbicide. In turn, Oleszczuk et al. (2014) investigated the effect of biocarbon on the activity of soil enzymes in the soil material contaminated with dikamba and 2,4-D. The use of biocarbon contributed to a significant increase in the activities of dehydrogenases, protease, urease, and alkaline phosphatase. The computed values of the biochemical soil quality index $\left(\mathrm{BA}_{21}\right)$ confirm the adverse effect of tebuconazole administered in a dose of $2.499 \mathrm{mg} \mathrm{kg}^{-1}$ (Table 6), which decreased $\mathrm{BA}_{21}$ value by $17.85 \%$, on average, compared to the control soil. The biostimulating substances used in the soil contaminated with tebuconazole dose of $2.499 \mathrm{mg} \mathrm{kg}^{-1}$ increased $\mathrm{BA}_{21}$ value by $15.63 \%$ in the case of compost and by $61.27 \%$, on average, in the case of bird droppings.

\subsection{Spring barley yield}

Tebuconazole caused changes also in the growth and development of spring barley (Fig. 6). The decrease in spring barley yield caused by its application to the soil ranged from $6.40 \%$ (at fungicide dose of $0.042 \mathrm{mg} \mathrm{kg}^{-1}$ ) to $17.93 \%$ (2.499 $\left.\mathrm{mg} \mathrm{kg}^{-1}\right)$. Jastrzębska and Kucharski (2007) made similar observations while investigating the effect of cyprodinil and a mixture of epoxiconazole and dimoxystrobin on the productivity of spring barley. In turn, Fromme et al. (2017), who analyzed azoxystrobin and flutriafol administered in a dose of $1.0 \mathrm{dm}^{3} \mathrm{ha}^{-1}$ and piraclostrobin in a dose of $0.78 \mathrm{dm}^{3} \mathrm{ha}^{-1}$, reported no significant changes in the growth and development of sorghum. Furthermore, Paul et al. (2011) demonstrated that the yield of maize grown on soil treated with azoxystrobin, piraclostrobin, propiconazole + trifloxystrobin, and propiconazole + azoxystrobin increased compared to that of maize from plots not exposed to these 


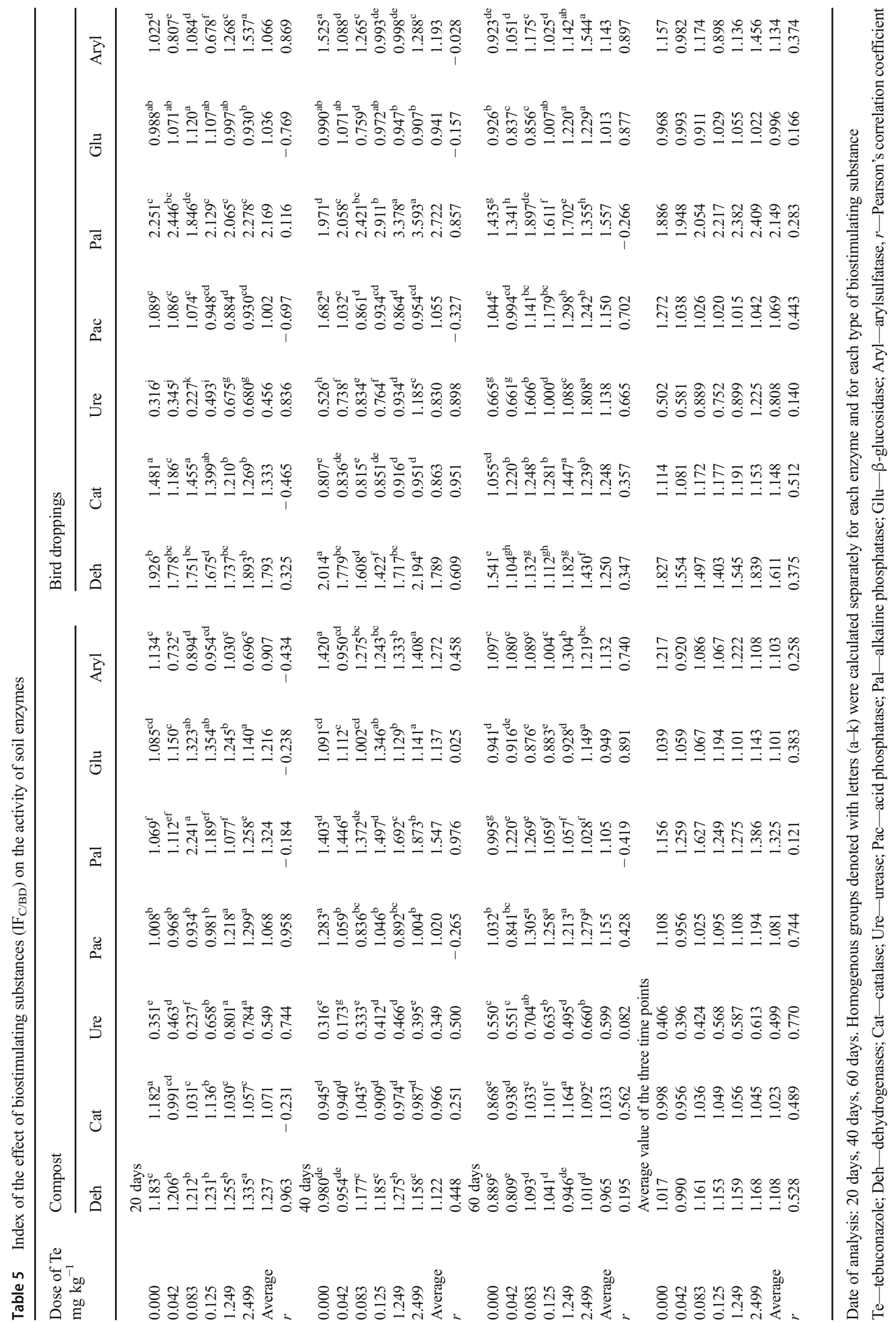


Table 6 Biochemical index of soil quality $\left(\mathrm{BA}_{21}\right)$

\begin{tabular}{|c|c|c|c|c|}
\hline \multirow{2}{*}{$\begin{array}{l}\text { Dose of Te } \\
\mathrm{mg} \mathrm{kg}^{-1}\end{array}$} & \multicolumn{3}{|c|}{ Date of analysis (days) } & \multirow[t]{2}{*}{ Average } \\
\hline & 20 & 40 & 60 & \\
\hline \multicolumn{5}{|l|}{ Control } \\
\hline 0.000 & $7.324^{\mathrm{b}}$ & $6.318^{\mathrm{c}}$ & $7.715^{\mathrm{b}}$ & 7.119 \\
\hline 0.042 & $7.471^{\mathrm{b}}$ & $7.125^{\mathrm{b}}$ & $8.875^{\mathrm{a}}$ & 7.824 \\
\hline 0.083 & $7.714^{\mathrm{b}}$ & $7.461^{\mathrm{b}}$ & $8.309^{\mathrm{a}}$ & 7.828 \\
\hline 0.125 & $7.610^{\mathrm{b}}$ & $7.721^{\mathrm{b}}$ & $8.284^{\mathrm{a}}$ & 7.872 \\
\hline 1.249 & $6.895^{\mathrm{c}}$ & $6.416^{\mathrm{c}}$ & $7.823^{\mathrm{b}}$ & 7.045 \\
\hline 2.499 & $6.080^{\mathrm{c}}$ & $4.833^{\mathrm{d}}$ & $6.632^{\mathrm{c}}$ & 5.848 \\
\hline Average & 7.182 & 6.646 & 7.940 & 7.256 \\
\hline$r$ & -0.967 & -0.862 & -0.852 & -0.912 \\
\hline \multicolumn{5}{|l|}{ Compost } \\
\hline 0.000 & $7.694^{\mathrm{b}}$ & $5.825^{\mathrm{d}}$ & $7.033^{\mathrm{b}}$ & 6.851 \\
\hline 0.042 & $8.035^{\mathrm{ab}}$ & $6.411^{\mathrm{c}}$ & $7.370^{\mathrm{b}}$ & 7.272 \\
\hline 0.083 & $8.345^{\mathrm{a}}$ & $8.016^{\mathrm{ab}}$ & $9.186^{\mathrm{a}}$ & 8.516 \\
\hline 0.125 & $8.810^{\mathrm{a}}$ & $8.682^{\mathrm{a}}$ & $8.751^{\mathrm{a}}$ & 8.748 \\
\hline 1.249 & $8.411^{\mathrm{a}}$ & $7.584^{\mathrm{b}}$ & $7.761^{b}$ & 7.919 \\
\hline 2.499 & $7.837^{\mathrm{b}}$ & $5.306^{\mathrm{d}}$ & $7.142^{\mathrm{b}}$ & 6.762 \\
\hline Average & 8.189 & 6.971 & 7.874 & 7.678 \\
\hline$r$ & -0.246 & -0.462 & -0.390 & -0.418 \\
\hline \multicolumn{5}{|c|}{ Bird droppings } \\
\hline 0.000 & $11.533^{\mathrm{a}}$ & $10.896^{\mathrm{b}}$ & $10.459^{\mathrm{b}}$ & 10.963 \\
\hline 0.042 & $11.137^{\mathrm{a}}$ & $11.172^{\mathrm{a}}$ & $9.388^{\mathrm{c}}$ & 10.566 \\
\hline 0.083 & $11.040^{\mathrm{a}}$ & $10.679^{\mathrm{b}}$ & $9.542^{\mathrm{c}}$ & 10.420 \\
\hline 0.125 & $11.126^{\mathrm{a}}$ & $10.225^{\mathrm{b}}$ & $9.335^{\mathrm{c}}$ & 10.229 \\
\hline 1.249 & $10.426^{\mathrm{b}}$ & $9.987^{\mathrm{c}}$ & $9.561^{\mathrm{c}}$ & 9.991 \\
\hline 2.499 & $9.890^{\mathrm{c}}$ & $9.278^{\mathrm{c}}$ & $9.125^{\mathrm{c}}$ & 9.431 \\
\hline Average & 10.859 & 10.373 & 9.568 & 10.267 \\
\hline$r$ & -0.962 & -0.907 & -0.490 & -0.905 \\
\hline
\end{tabular}

Homogenous groups denoted with letters $(a-d)$ were calculated separately for each type of biostimulating substance

Te - tebuconazole; $r$-Pearson's correlation coefficient preparations. Also, Ijaz et al. (2015) in their study with Torpex, Folicur, Proline, Caramba, Otrivia, and Cantus preparations confirmed the fact that when fungicides are applied following producers' recommendations, they may increase the yield of crops, including winter rapeseed investigated in their study. In our experiment, compost and bird droppings turned out to be ineffective in improving spring barley yield. This could, most likely, be due to the lower amount of nitrogen released during degradation of organic matter in the soil amended with compost and bird droppings. This amount of nitrogen could be insufficient to cover nutritional needs of the plants, and this could contribute to disorders in spring barley yield. Both biostimulating substances not only did not alleviate the adverse effect of tebuconazole on spring barley growth and development but even aggravated its toxic effect. In our previous study (Baćmaga et al. 2018), we also demonstrated that Lignohumat Super and Bioilsa N 12.5 preparations did not improve the health status of spring wheat in the soil contaminated with chlorothalonil. Values of the resistance index (RS) computed for spring barley in our study confirm the adverse effect of tebuconazole applied in a dose of $2.499 \mathrm{mg} \mathrm{kg}^{-1}$ (Fig. 7). The addition of biostimulating substances to the soil treated with this dose of tebuconazole increased spring barley resistance to this fungicide, with a stronger positive effect observed for bird droppings than for compost. Chang et al. (2007) claimed that soil supplementation with organic fertilizers had the key impact on the improvement of the physicochemical properties of soil, which in turn resulted in plant growth stimulation and plant yield increase.

\subsection{Tebuconazole degradation in the soil}

Degradation of tebuconazole in the soil was determined by the dose of the active substance and by the type of the biostimulating substance (Fig. 8). In the soil without the addition of biostimulating substances, degradation of tebuconazole
Fig. 6 Spring barley yield, g $\operatorname{pot}^{-1}$. Te-tebuconazole

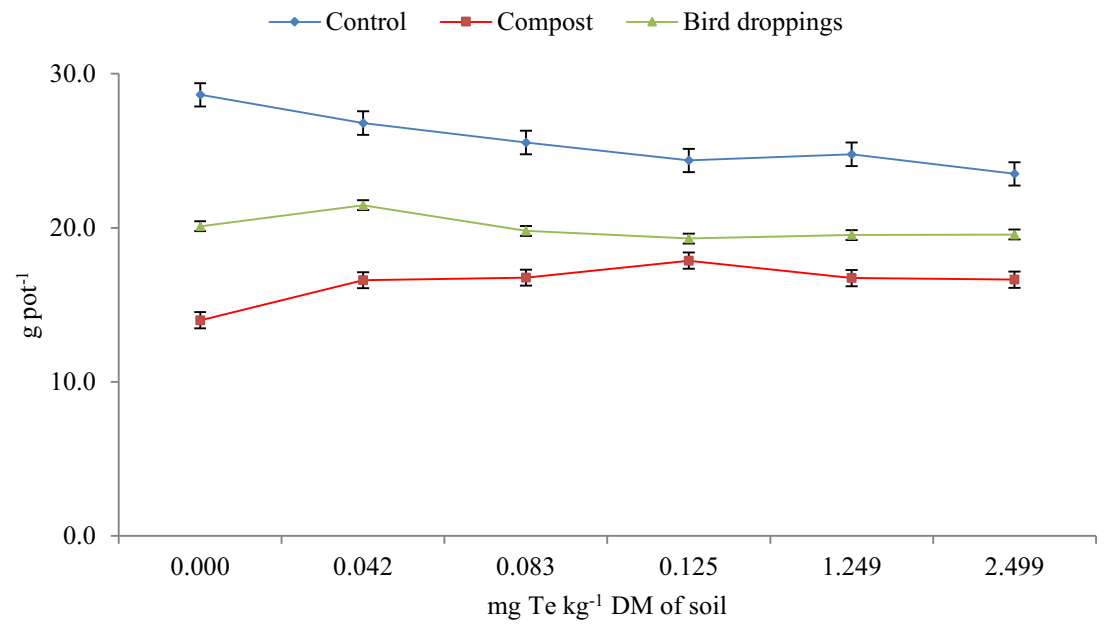


Fig. 7 Spring barley resistance to tebuconazole. Te - tebuconazole; RS - index of spring barley resistance to tebuconazole

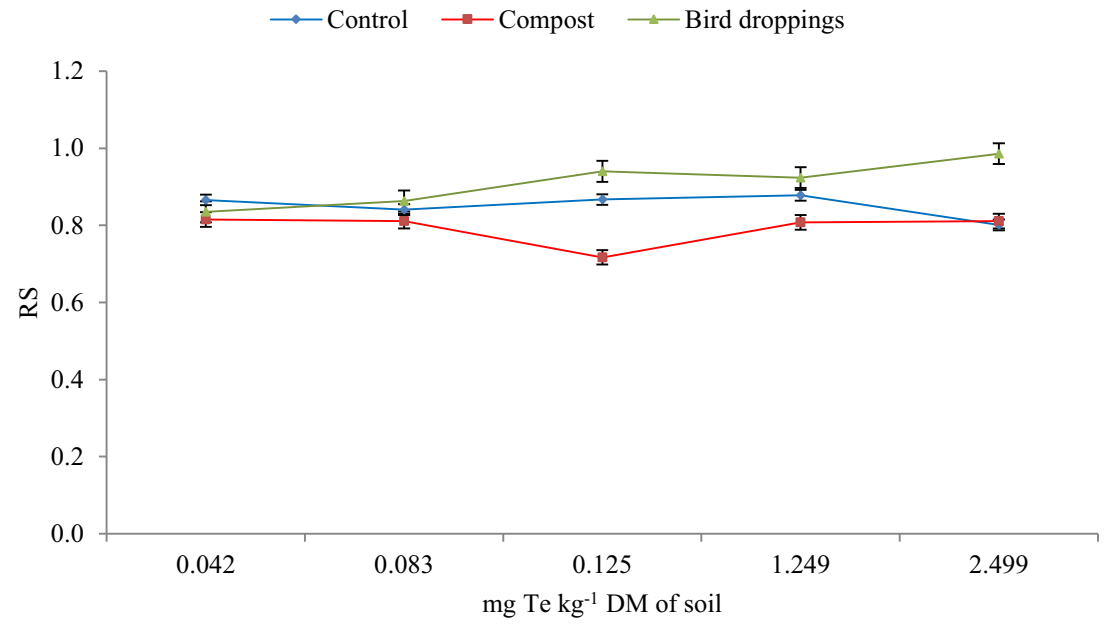

introduced in the dose of $0.083 \mathrm{mg} \mathrm{kg}^{-1} \mathrm{DM}$ of soil reached $56.78 \%$, whereas in the soil exposed to its dose of $2.499 \mathrm{mg} \mathrm{kg}^{-1} \mathrm{DM}$ of soil, it reached $38.37 \%$. Muñoz-Leoz et al. (2013) suggest that degradation of pesticides depends largely on the type of the active substance. They demonstrated various extent of degradation of difenoconazole, deltamethrin, and ethofumesate used in a dose of $5 \mathrm{mg} \mathrm{kg}^{-1}$, i.e., $52 \%, 69 \%$, and $89 \%$, respectively. In our study, the addition of compost to the soil treated with the contaminating dose of tebuconazole (2.499 $\mathrm{mg} \mathrm{kg}^{-1} \mathrm{DM}$ of soil) contributed to its degradation by $56.15 \%$, whereas the addition of bird droppings - by $73.35 \%$. In the case of $0.083 \mathrm{mg} \mathrm{kg}^{-1}$ dose, the active substance was degraded by $55.82 \%$ in the soil samples with both compost and bird droppings. Singh et al. (2010) demonstrated a high effectiveness of compost in degrading azoxystrobin. In turn, in our previous experiment (Baćmaga et al. 2018), we evaluated the effectiveness of Bioilsa N 12.5 and Lignohumat Super preparations in chlorothalonil degradation and demonstrated its faster degradation in the soil with the addition of Bioilsa $\mathrm{N}$ 12.5 than in the control soil, while we did not show such a dependency for Lignohumat Super.

\section{Conclusions}

This study suggests that tebuconazole can affect the stability and health status of soil ecosystems by modifying their biological properties. The high susceptibility of soil microorganisms and enzymes to stress conditions allows considering them as reliable environmental bioindicators. The strive for eliminating the adverse effects of fungicides on soil microbiome through the use of appropriate remediation methods, like, e.g., biostimulation, seems to be of great ecological concern. Tebuconazole administered to the soil in doses of $0.042 \mathrm{mg} \mathrm{kg}^{-1}$ and $0.083 \mathrm{mg} \mathrm{kg}^{-1}$ had a stimulating effect on the proliferation of organotrophic bacteria, actinobacteria, and fungi. However, when used in a dose of $2.499 \mathrm{mg} \mathrm{kg}^{-1}$, it became toxic to these microorganisms. The tested fungicide exerted a negative effect also on the biochemical properties of soil. When administered to the soil in a dose of $2.499 \mathrm{mg} \mathrm{kg}^{-1}$, it strongly inhibited activities of all analyzed soil enzymes. In addition, tebuconazole had a negative impact on spring barley development, which was manifested in its reduced yield. Soil supplementation with compost and bird droppings elicited various effects on the condition of soil environment.
Fig. 8 Percentage degradation of tebuconazole in the soil after 40 days of the experiment. Tetebuconazole. Homogenous groups denoted with letters $(\mathrm{a}-\mathrm{c})$ were calculated for the percentage degradation of tebuconazole in soil $\square$ Control $\square$ Compost $\square$ Bird droppings

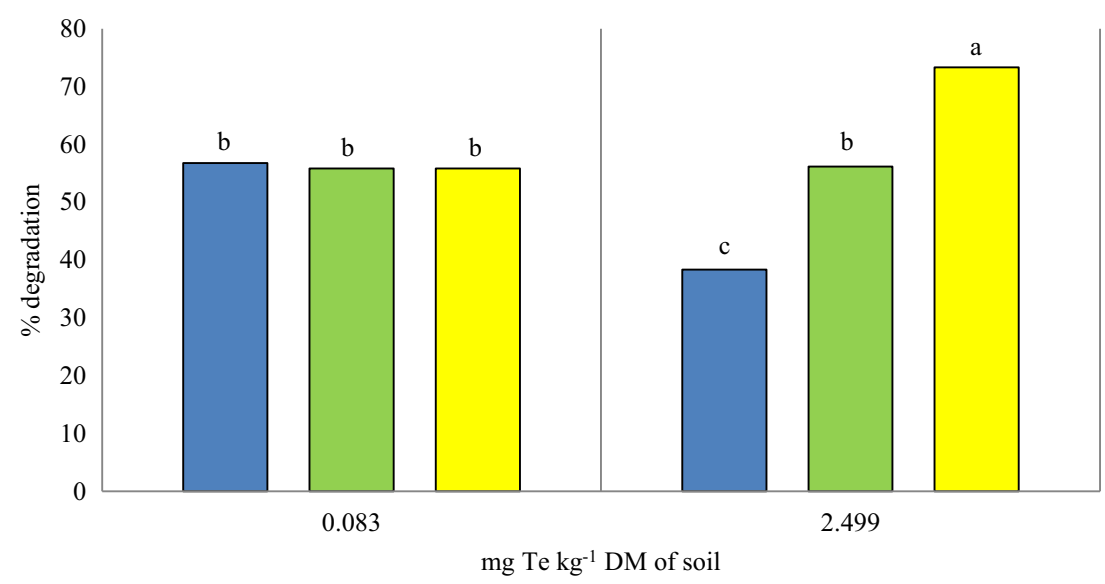


Funding information This study was supported by statutory research funds from the Ministry of Science and Higher Education.

\section{Compliance with ethical standards}

Conflict of interest The authors declare that they have no conflict of interest.

Open Access This article is distributed under the terms of the Creative Commons Attribution 4.0 International License (http:// creativecommons.org/licenses/by/4.0/), which permits unrestricted use, distribution, and reproduction in any medium, provided you give appropriate credit to the original author(s) and the source, provide a link to the Creative Commons license, and indicate if changes were made.

\section{References}

Adams GO, Fufeyin PT, Okoro SE, Ehinomen I (2015) Bioremediation, biostimulation and bioaugmentation: a review. Int J Environ Biorem Biodegrad 3(1):28-39

Ahemad M, Khan MS (2012) Effect of fungicides on plant growth promoting activities of phosphate solubilizing Pseudomonas putida isolated from mustard (Brassica compestris) rhizosphere. Chemosphere 86:945-950

Baćmaga M, Boros E, Kucharski J, Wyszkowska J (2012) Enzymatic activity in soil contaminated with the Aurora 40 WG herbicide. Environ Prot Eng 38(1):91-102

Baćmaga M, Wyszkowska J, Kucharski J (2018) The influence of chlorothalonil on the activity of soil microorganisms and enzymes. Ecotoxicology 27:1188-1202

Banach-Szott M, Debska B, Rosa E (2014) Effect of soil pollution with polycyclic aromatic hydrocarbons on the properties of humic acids. J Soils Sediments 14:1169-1178

Boros E, Baćmaga M, Kucharski J, Wyszkowska J (2011) The usefulness of organic substances and plant growth in neutralizing the effects of zinc on the biochemical properties of soil. Fresenius Environ Bull 20(12):3101-3310

Borowik A, Wyszkowska J, Wyszkowski M (2017) Resistance of aerobic microorganisms and soil enzyme response to soil contamination with Ekodiesel ultra fuel. Environ Sci Pollut Res 24:24346-24363

Bragança I, Mucha AP, Tomasino MP, Santos F, Lemos PC, DelerueMatos C, Domingues VF (2019) Deltamethrin impact in a cabbage planted soil: degradation and effect on microbial community structure. Chemosphere 220:1179-1186

Chaer G, Fernandes M, Myrold D, Bottomley P (2009) Comparative resistance and resilience of soil microbial communities and enzyme activities in adjacent native forest and agricultural soils. Microb Ecol 58:414-424

Chang EH, Chung RS, Tsai YH (2007) Effect of different application rates of organic fertilizer on soil enzyme activity and microbial population. Soil Sci Plant Nutr 53(2):132-140

D'Hose T, Cougnon M, De Vliegher A, Van Bockstaele E, Reheul D (2012) Influence of farm compost on soil quality and crop yields. Arch Agron Soil Sci 58(1):S71-S75

Fang H, Han L, Cui Y, Xue Y, Cai L, Yu Y (2016) Changes in soil microbial community structure and function associated with degradation and resistance of carbendazim and chlortetracycline during repeated treatments. Sci Total Environ 572(1):1203-1212

Fromme DD, Price T, Lofton J, Isakeit T, Schnell R, Dodla S, Stephenson D, Grichar WJ, Shannon K (2017) Effect of fungicide applications on grain sorghum (Sorghum bicolor L.) growth and yield. Int J Agron 7
García-Gil JC, Kobza J, Soler-Rovira P, Javoreková S (2013) Soil microbial and enzyme activities response to pollution near an aluminium smelter. Clean: Soil, Air, Water 41(5):485-492

Guo P, Zhu L, Wang J, Wang J, Xie H, Lv D (2015) Enzymatic activities and microbial biomass in black soil as affected by azoxystrobin. Environ Earth Sci 74:1353-1361

Hale HK, Fawy HA (2011) Effect of different levels of humic acids on the nutrient content, plant growth, and soil properties under conditions of salinity. Soil Water Res 6(1):21-29

Hatvani L, Manczinger L, Kredics L, Szekeres A, Antal Z, Vágvölgyi C (2006) Production of Trichoderma strains with pesticide polyresistance by mutagenesis and protoplast fusion. Anton Leeuw Int J G 89:387-393

Ijaz M, Mahmood K, Honermeier B (2015) Interactive role of fungicides and plant growth regulator (Trinexapac) on seed yield and oil quality of winter rapeseed. Agronomy 5:435-446

Jastrzębska E, Kucharski J (2007) Dehydrogenases, urease and phosphatases activities of soil contaminated with fungicides. Plant Soil Environ 53(2):51-57

Kaczyńska G, Borowik A, Wyszkowska J (2015) Soil dehydrogenases as an indicator of contamination of the environment with petroleum products. Water Air Soil Pollut 226(11):372

Kaczyński P (2017) Large-scale multi-class herbicides analysis in oilseeds by rapid one-step QuEChERS-based extraction and cleanup method using liquid chromatography-tandem mass spectrometry. Food Chem 230:411-422

Kadian N, Malik A, Satya S, Dureja P (2012) Effect of organic amendments on microbial activity in chlorpyrifos contaminated soil. J Environ Manage 95:S199-S202

Kucharski J, Tomkiel M, Baćmaga M, Borowik A, Wyszkowska J (2016) Enzyme activity and microorganisms diversity in soil contaminated with the boreal 58 WG herbicide. J Environ Sci Health, Part B 51(7): 446-454

Li Y, Dong F, Liu X, Xu J, Han Y, Zheng Y (2015) Enantioselectivity in tebuconazole and myclobutanil non-target toxicity and degradation in soils. Chemosphere 122:145-153

Lo CC (2010) Effect of pesticides on soil microbial community. J Environ Sci Health, Part B 45(5):348-359

Mohiuddin M, Mohammed MK (2013) Influence of fungicide (carbendazim) and herbicides (2, 4-D and metribuzin) on nontarget beneficial soil microorganisms of Rhizospheric soil of tomato crop. J Environ Sci Toxicol Food Technol 5(1):2319-2399

Muñoz-Leoz B, Garbisu C, Charcosse JY, Sánchez-Pérez JM, Antigüedad I, Ruiz-Romera E (2013) Non-target effects of three formulated pesticides on microbially-mediated processes in a clayloam soil. Sci Total Environ 449:345-354

Muñoz-Leoz B, Ruiz-Romera E, Antigüedad I, Garbisu C (2011) Tebuconazole application decreases soil microbial biomass and activity. Soil Biol Biochem 43:2176-2183

Nowak KM, Girardi C, Miltner A, Gehre M, Schäffer A, Kästner M (2013) Contribution of microorganisms to non-extractable residue formation during biodegradation of ibuprofen in soil. Sci Total Environ 445-446:377-384

Oleszczuk P, Jośko I, Futa B, Pasieczna-Patkowska S, Pałys E, Kraska P (2014) Effect of pesticides on microorganisms, enzymatic activity and plant in biochar-amended soil. Geoderma 214-215:10-18

Orwin KH, Wardle DA (2004) New indices for quantifying the resistance and resilience of soil biota to exogenous disturbance. Soil Biol Biochem 36:1907-1912

Paul PA, Madden LV, Bradley CA, Robertson AE, Munkvold GP, Shaner G, Wise KA, Malvick DK, Allen TW, Grybauskas A, Vincelli P, Esker P (2011) Meta-analysis of yield response of hybrid field corn to foliar fungicides in the U.S. Corn Belt. Phytopathology 101: $1122-1132$

Pimmata P, Reungsang A, Plangklang P (2013) Comparative bioremediation of carbofuran contaminated soil by natural attenuation, 
bioaugmentation and biostimulation. Int Biodeterior Biodegrad 85: 196-204

Riah W, Laval K, Laroche-Ajzenberg E, Mougin C, Latour X, Trinsoutrot-Gattin I (2014) Effects of pesticides on soil enzymes: a review. Environ Chem Lett 12:257-273

Saha A, Pipariya A, Bhaduri D (2016) Enzymatic activities and microbial biomass in peanut field soil as affected by the foliar application of tebuconazole. Environ Earth Sci 75:558

Sanchez-Hernandez JC, Sandoval M, Pierart A (2017) Short-term response of soil enzyme activities in a chlorpyrifos-treated mesocosm: use of enzyme-based indexes. Ecol Indic 73:525-535

Sehnem NT, Souza-Cruz P, Peralba MR, MAZ A (2010) Biodegradation of tebuconazole by bacteria isolated from contaminated soils. J Environ Sci Health, Part B 45(1):67-72

Singh N, Singh SB, Mukerjee I, Gupta S, Gajbhiye VT, Sharma PK, Goel M, Dureja P (2010) Metabolism of 14C-azoxystrobin in water at different pH. J Environ Sci Health, Part B 45:123-127

Statsoft, Inc, Statistica (2018) Data analysis software system, version 13.1. <http://www.statsoft.com.>

Strachel R, Wyszkowska J, Baćmaga M (2017) The role of compost in stabilizing the microbiological and biochemical properties of zincstressed soil. Water, Air, Soil Pollut 228:349

Strickland TC, Potter TL, Joo H (2004) Tebuconazole dissipation and metabolism in Tifton loamy sand during laboratory incubation. Pest Manage Sci 60:703-709

Sułowicz S, Piotrowska-Seget Z (2016) Response of microbial communities from an apple orchard and grassland soils to the first time application of the fungicide tetraconazole. Ecotoxicol Environ Saf 124:19-201

Swędrzyńska D, Małecka-Jankowiak I (2017) The impact of tillaging spring barley on selected chemical, microbiological, and enzymatic soil properties. Pol J Environ Stud 26(1):303-313

Wang C, Wang F, Zhang Q, Liang W (2016) Individual and combined effects of tebuconazole and carbendazim on soil microbial activity. Eur J Soil Biol 72:6-13

Wang F, Wang Z, Zhang B, Zhang Q (2017) Degradation and adsorption of tebuconazole and tribenuron-methyl in wheat soil, alone and in combination. Chil J Agric Res 77(3):281-286
Wang X, Hou X, Liang S, Lu Z, Hou Z, Zhao X, Sun F, Zhang H (2018) Biodegradation of fungicide tebuconazole by Serratia marcescens strain B1 and its application in bioremediation of contaminated soil. Int Biodeterior Biodegrad 127:185-191

Wang X, Song M, Wanga Y, Gao C, Zhang Q, Chu X, Fang H, Yu Y (2012) Response of soil bacterial community to repeated applications of carbendazim. Ecotoxicol Environ Saf 75:33-39

World Reference Base of Soil Resources (2014) International soil classification system for naming soils and creating legends for soil maps. World Soils Resources Reports 106. FAO, Rome, Italy

Wu X, Xu J, Liu Y, Dong F, Liu X, Zhang W, Zheng Y (2015) Impact of fluxapyroxad on the microbial community structure and functional diversity in the silty-loam soil. J Integr Agric 14(1):114-124

Wyszkowska J, Borowik A, Kucharski J, Baćmaga M, Tomkiel M, Boros-Lajszner E (2013b) The effect of organic fertilizers on the biochemical properties of soil contaminated with zinc. Plant Soil Environ 59(11):500-504

Wyszkowska J, Borowik A, Kucharski M, Kucharski J (2013a) Applicability of biochemical indices to quality assessment of soil polluted with heavy metal. J Elementol 18(4):723-732

Xu XH, Liua XM, Zhanga L, Mua Y, Zhua XY, Fanga JY, Lia SP, Jianga JD (2018) Bioaugmentation of chlorothalonil-contaminated soil with hydrolytically or reductively dehalogenating strain and its effect on soil microbial community. J Hazard Mater 351:240-249

Ye X, Dong F, Lei X (2018) Microbial resources and ecology—microbial degradation of pesticides. Nat Resour Conserv Res 22-28

Youness M, Sancelme M, Combourieu B, Besse-Hoggan P (2018) Identification of new metabolic pathways in the enantioselective fungicide tebuconazole biodegradation by Bacillus sp. 3B6. J Hazard Mater 351(51):160-168

Publisher's note Springer Nature remains neutral with regard to jurisdictional claims in published maps and institutional affiliations. 